\title{
Meaning in Life During Covid-19 Pandemic and Social Interaction Anxiety : The Relevant Facets
}

\author{
Mayurakshee Gangopadhyay \\ Department of Human Development, Dum Dum Motijheel College, Kolkata, India \\ E-mail: psychologistm87@gmail.com
}

\begin{abstract}
The meaning of life is steadily altering in the Covid-19 pand emic scenario. Since birth, life and living have been the major preoccupation of every human being. However, there remains a constant possibility of death owing to a pandemic breakout. The ways of social interaction and associated psychosocial issues are also of great importance in the present condition. This study thus aimed at finding out the interrelationship between meaning in life and social interaction anxiety amongyoung adults. The study used a quantitative research method with the help of the Meaning in Life Questionnaire by Steger and Social Interaction Anxiety Scale by Mattick and Clarke on 100 samples of both the Gender, i.e., male and female aged between 21 to 25 years. The findings showed that meaning in life has a significantnegative correlation with social interaction anxiety. And social interaction anxiety is found out to be negatively predicted by meaning in life.
\end{abstract}

Keywords: Meaning in Life, Social Interaction Anxiety, Young Adults, Covid-19 Pandemic.

\begin{abstract}
Abstrak
Dalam skenario pandemi Covid-19 makna hidup berangsur-angsur berubah. Bagi setiap manusia hidup dan kehidupan adalah perhatian utama sejak lahir. Tetapi karena wabah pandemi ada ancaman konstan terhadap kehidupan. Cara interaksi sosial dan masalah psiko-sosial yang terkaitjuga sangat penting dalam kondisi saat ini. Penelitian ini bertujuan untuk mengetahui hubungan antara makna dalam hidup dan kecemasan interaksi sosial di kalangan dewasa muda. Penelitian ini menggunakan metode pen elitian kuantitatif dengan bantuan Meaning in Life Questionnaire dari steger, dan Social Interaction Anxiety Scale dari Mattick dan Clarke dengan jumlah sampel 100 orang baik jenis kelamin, yaitu laki-laki dan perempuan berusia antara 21 sampai 25 tahun. Hasil penelitian menunjukkan bahwa makna hidup memiliki korelasi negatif yang signifikan dengan kecemasan interaksi sosial. Dan kecemasan interaksi sosial ditemukan diprediksi secara negatif oleh makna dalam hidup.
\end{abstract}

Kata Kunci: Makna Hidup, Kecemasan Interaksi Sosial, Dewasa Muda, Covid -19.

\section{INTRODUCTION}

Living in harmony is the meaning of life (Carreno et al., 2021). It is a process of existence that enables living beings to actand react effectively, evaluate wisely, and evolve meaningfully through physical and psychological growth and development. The perception of individuals about the culture and value system in which they live, set their goals, expectations, standards, and concerns denote their quality of life (WHO). The degree to which an individual is healthy, comfortable, and able to participate in or enjoy life events is the individual's quality of life (Britannica). Quality of life is a subjective concept where it can depend on an individual's personal experience or on the living conditions of that individual. Satisfaction with life can be a parameter to identify the quality of life. Again capabilities of an individual can also be a parameter to denote the quality of life. The meaning of quality of life varies from one person to another.

* Copyright (c) 2021 Mayurakshee Gangopadhyay

This work is licensed under a Creative Commons Attribution-ShareAlike 4.0 International License

Received: April 11, 2021; In Revised : July 1, 2021; Accepted : July 9, 2021 
Khazanah Sosial, Vol. 3 No. 3 : 130-137

Meaning in Life During Covid-19 Pandemic and Social Interaction Anxiety :The Relevant Facets Mayurakshee Gangopadhyay

That is why it is multifaceted, and physical, social, emotional, and psychological well-being are closely related (Mendlowicz \& Stein, 2000; Sushma etal., 2016).

Meaning in life can be felt if a person has a quality life. It reflects the beauty of living and how effectively a person interacts within oneself and with society makes life meaningful (Wong, 2013). Thus meaning in life is not only a subjective but also is a social concept. People grow through social interaction and grow to maturity with an experience they gather from the interaction (Gangopadhyay, 2021). Thus in adding or realizing meaning in life, the social and psychological well-being of individuals is pivotal. As interaction with society keeps an individual growing, when that interactiongets hindered for any reason, the growth can be affected negatively. Like social interaction, anxiety or social phobia restricts an individual from communicating with society. So to have a quality of life, social interactions must be sound, else it may resultadversely. Social anxiety hasrestricted interpersonal relationships(Leray etal., 2011; Xu et al., 2012). In the present scenario of the covid-19 pandemic, people are dealing with serious mental health issues. There is a constant threat to life, and human beings' social lives are controlled or abruptly changed to protect themselvesfrom the spread of the virus (Kharshiing et al.,2021). Thus there exists a scope to develop social interaction anxiety or social phobia among many other possible mental health issues.

There have been previous studiesin thisarea, such as research from Mendlowicz and Stein (2000), Sushma, Padmaja, and Agarwal(2016), Chou et.al(2020), Hemanth(2020), Baber(2021), and Banerjee et.al(2020). Still, research gaps were found while reviewing the literature, so research is needed to assess the relationship between meaning in life and social interaction anxiety among young adults given the COVID-19 pandemic scenario. This study aimed to assess the impact of gender (male and female) on meaning in life and on social interaction anxiety of young adults, to assess the relationship between meaning in life and social interaction anxiety, and to assess whether social interaction anxiety can be predicted by meaning in life. So the main goal is to see the interrelationship between the meaning in life and the social interaction anxiety during covid-19 pandemic.

\section{RESEARCHMETHOD}

This research had used the quantitative research method.

\section{Null Hypothesis}

1. Gender (Male andFemale) has no significant impacton the meaningin life of youngadults.

2. Gender (Male and Female) has no significant impact on the social interaction anxiety of young adults.

3. There is no significant relationship between meaning in life and social interaction anxiety.

4. The social interaction anxiety cannotbe predicted by the meaning in life.

\section{Sample}

The samples were collected using a simple random sampling method. The sample size was 100 aged between 21 to 25 years, of which 50 were male, and 50 were female.

\section{Tools used}

The following tools were used in collecting data from the samples. 
Khazanah Sosial, Vol. 3 No. 3 : 130-137

Meaning in Life During Covid-19 Pandemic and Social Interaction Anxiety :The Relevant Facets Mayurakshee Gangopadhyay

\section{GeneralInformationSchedule}

The General Information Schedule was used to get the demographic data. A questionnaire has been prepared to acquire knowledge from the sample such asage, occupation, hobbies, social involvement, etc.

\section{Meaning in Life Questionnaire: Steger (2005)}

This tool can be used to help people understand and track their perceptions about their lives. The questionnaire has two subscales representing two dimensions of meaning in life: (1) Presence of Meaning: how much respondentsfeel their lives have meaning and (2) Search for Meaning: how much respondents strive to find meaning and understanding in their lives. It has a reliability of $\alpha=.84-.91$ for each subscale.

\section{Social Interaction Anxiety Scale: Mattick and Clarke (1998)}

The SIAS is a 20 item self-report scale designed to measure social interaction anxiety defined as "distress when meeting and talking with other people." This tool helps track social anxiety symptoms over time and maybe helpful as a part of an assessmentfor social phobia or other anxiety-related disorders.

\section{Statistical Analysis}

Descriptive Statistics, One-WayANOVA, Correlation, and Regression Analysis, are used to verify the hypotheses. All the statistical analysis wascarried out in "SPSS-20".

\section{RESULT AND DISCUSSION}

\section{Result}

Table 1. Descriptive Statistics

\begin{tabular}{|c|c|c|c|c|c|}
\hline \multicolumn{6}{|c|}{ Group Statistics } \\
\hline & Subjects & $\mathrm{N}$ & Mean & Std. Deviation & Std. Error Mean \\
\hline \multirow[t]{2}{*}{ Social Interaction Anxiety } & Male & 50 & 40.16 & 4.569 & .646 \\
\hline & Female & 50 & 46.60 & 10.375 & 1.467 \\
\hline \multirow[t]{2}{*}{ Meaning In Life } & Male & 50 & 63.36 & 10.073 & 1.424 \\
\hline & Female & 50 & 52.84 & 16.680 & 2.359 \\
\hline
\end{tabular}

Source: Processed by Researcher ( 2021)

Table 1 shows the descriptive statistics, i.e., the mean and standard deviation of the samples of both genders, i.e., male and female. It reveals that the mean of social interaction anxiety for females is higher than that of the males, and them ean of meaning in life is higher among males than that of females.

Table 2: Summarized Result of One Way ANOVA for Meaning in Life and Social Interaction Anxiety with respect to Gender

\begin{tabular}{|c|c|c|c|c|c|c|c|}
\hline & & ANOVA & & & & & \\
\hline & & Sum of Squares & $\mathrm{df}$ & Mean Square & $\mathrm{F}$ & Sig. & \\
\hline \multirow[t]{3}{*}{ Social Interaction Anxiety } & $\begin{array}{l}\text { Between } \\
\text { Groups }\end{array}$ & 1036.840 & 1 & 1036.840 & $16.137^{* *}$ & .000 & \\
\hline & Within Groups & 6296.720 & 98 & 64.252 & & & \\
\hline & Total & 7333.560 & 99 & & & & \\
\hline \multirow[t]{3}{*}{ Meaning In Life } & $\begin{array}{l}\text { Between } \\
\text { Groups }\end{array}$ & 2766.760 & 1 & 2766.760 & $14.574^{* *}$ & .000 & \\
\hline & Within Groups & 18604.240 & 98 & 189.839 & & & ${ }^{* *} \mathrm{p}<0.01$ \\
\hline & Total & 21371.000 & 99 & & & & \\
\hline
\end{tabular}

Source: Processed by Researcher (2021)

Table 2 show, The findings of One Way ANOVA indicate that the im pact of Gender on the meaning in life and on the social interaction anxiety is significant, thus leading to the rejection of the null 
Khazanah Sosial, Vol. 3 No. 3 : 130-137

Meaning in Life During Covid-19 Pandemic and Social Interaction Anxiety :The Relevant Facets Mayurakshee Gangopadhyay

hypothesis-I, i.e., Gender (Male and Female) has no significant impact on the meaning in life of young adults and null hypothesis-II, i.e., Gender (Male and Female) has no significant impact on the social interaction anxiety of young adults. And thus, the result leads to acceptance of the alternative hypotheses.

Table 3: Summarized Result of Correlation for Meaning in Life and Social Interaction Anxiety

\begin{tabular}{|c|c|c|c|}
\hline \multicolumn{3}{|c|}{ Correlation } & \\
\hline \multirow{4}{*}{ Meaning in Life } & \multicolumn{2}{|c|}{ Social Interaction Anxiety } & \\
\hline & Pearson Correlation & $-.848^{* *}$ & \\
\hline & Sig (2-tailed) & .000 & \\
\hline & $\mathbf{N}$ & 100 & ${ }^{* *} \mathrm{p}<0.01$ \\
\hline
\end{tabular}

Source: Processed by Researcher ( 2021)

From table 3, it can be seen that correlation is significant between the meaning in life and social interaction anxiety. Therefore the null hypothesis-III, i.e., there is no significant relationship between meaning in life and social interaction anxiety, is rejected, and the alternativehypothesis is accepted.

Table 4: Regression Coefficient between Social Interaction Anxiety with Meaning in Life

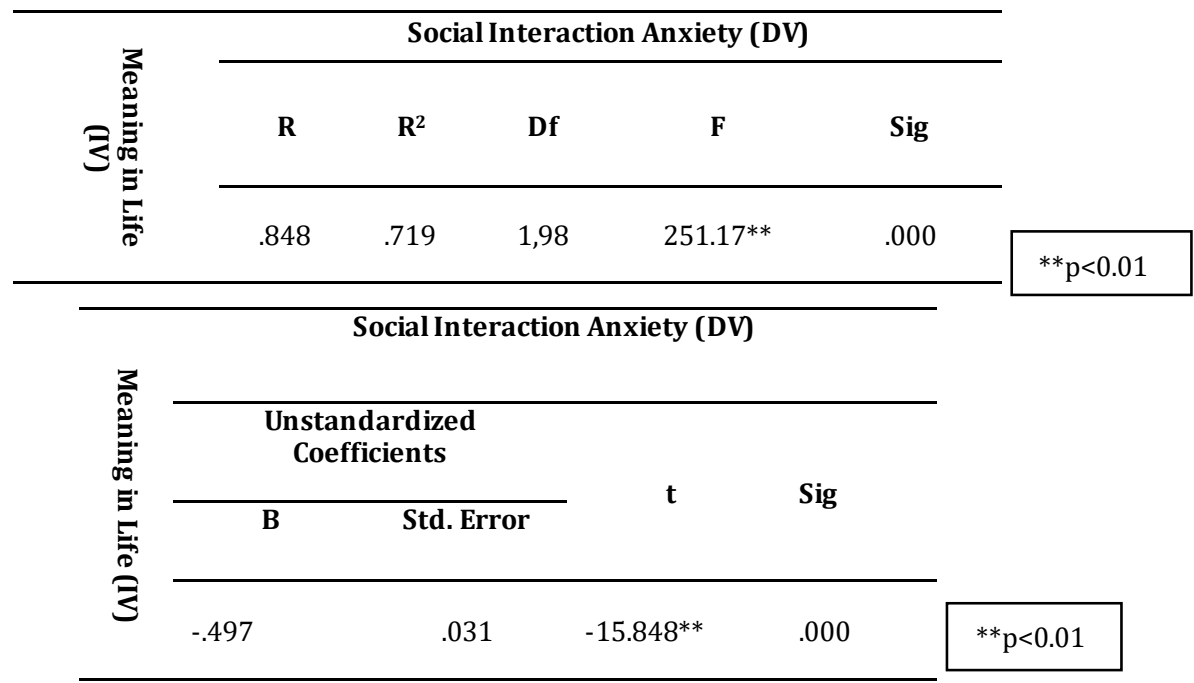

Source: Processed by Researcher ( 2021)

In table 4, regression equationshave been generated for social interaction anxiety as a dependent variable and meaning in life as the independent variable for the entire sample. The highest Regression Coefficient for the dimension of social interaction anxiety accounts for 71.9 percent variability. The $F$ values are found out to be significant for social interaction anxiety. The Unstandardized BetaCoefficients indicates that meaning in life negatively predicts social interaction anxiety. The above analyses of regression coefficientslead to rejection of the null hypothesis-IV, i.e., the social interaction anxiety cannot be predicted by the meaningin life.

\section{Discussion}

Meaning in life has all its roots in positive psychology, where individuals can find the meaning of their life and search for it (Wong, 2014). The healthy well-being of individuals adds meaning to their lives. Finding meaning in life appears to be a difficult thing to claim in the covid-19 pandemic scenario, where 
Khazanah Sosial, Vol. 3 No. 3 : 130-137

Meaning in Life During Covid-19 Pandemic and Social Interaction Anxiety :The Relevant Facets Mayurakshee Gangopadhyay

the threat of death is always knocking on the human mind, or it could be truethat finding meaning in life appears to be more relevant where life stands in front of true uncertainties dueto pandemic. In both cases, the search or quest to find or add meaning to life is important. The present study thus had tried to view the facets of it.

Humans are social beings, and thus, they constantly strive for interaction with society(King et al, 2011). The entire life span of human beings is fruit to effective social interactions. But during recent pandemic situations, people are mostly avoidingsocial interactions where face-to-face communication is required, helping reduce the spread of the virus (Banerjee \& Rai, 2020). That is the need of the hour. But it is also true that constant practice of least social interaction may lead to serious psychological issues like developing anxiety or phobia from social situations. Thus this present study also had tried to see whether such issues are prevalentor not.

From the study's findings, it had been seen that based on Gender, there was a significant difference in terms of meaning in life and social interaction anxiety. That means the way males or females interact with society and how they perceive their lives are significantly different. Thepsyche of every individual is different, and gender identity makes the difference broader, thus creating the variation prominent and significant.

Again it was also found out that the meaning in life and social interaction anxiety were negatively correlated. A negative correlation means with the increase in one dimension the other will decrease. Thus, with the increase in the meaning in life in an individual, the social interaction anxiety of that person will decrease and vice versa. The more human beings are social, the more they find meaning in their lives because personal growth depends on the social variables. With the constantinteraction with society, every individual adds meaning to their life. If a person has social interaction anxiety, then it will be difficult to communicate the needs to the social variables, thus hindering that individual's psychosocial development, which leads to decreasing meaning in thatperson's life. In this way meaning in life and social interaction anxiety are negatively correlated. This result can be supported by previous research works (Mendlowicz \& Stein, 2000; Sushma et al.,2016).

Now in the scenario of the covid-19 pandemic, there is a gradual hike in avoidance of social interaction. Though this habit is required, it has negative effects like social anxiety or social phobia. Through interaction with the samples, it has been found that because of covid-19 pandemic outbreak, people are not feeling interested in direct social interaction and are mostly avoiding such situations without intending to do it (Kharshiing etal., 2021). But before the covid-19 pandemicthey used to interact in those situations with ease. Even they arefeeling frightened to go to gatherings or eating out or attending any function which was not present in them in those days when there was no clue of the covid-19 pandemic. This proves how people are gradually developing social interaction anxiety, which may affect their psychosocial development. Adding meaning to life happens without prior notice. Through day-to-day experience, life becomes meaningful. But when life is dealing with the everyday threat of death, the meanings attached to life become more intense. While interacting with the samples, many of them reported that they do not feel like living with the threat of covid-19 and will accept whatever comes to their lives. Again, many of them also reported that they wish to do whatever they can before they die due to this pandemic or whatever reason. That discrimination of thought is natural, and that is the law of individual differences. Thisalso had made the research findings relevant that meaning in life is better when social interaction anxiety is less. 
Khazanah Sosial, Vol. 3 No. 3 : 130-137

Meaning in Life During Covid-19 Pandemic and Social Interaction Anxiety :The Relevant Facets Mayurakshee Gangopadhyay

\section{IMPLICATION}

There is almosta uniform pattern where anxiety disorders lead to serious mental illness and impair the quality of life and psychosocial functioning of individuals (Mendlowicz \& Stein, 2000; Sushma et al., 2016). Social phobia and social anxiety are harm ful to the qual ity of life and well-being of any individual. It is an impairing condition that creates behavioral agitation when challenges are met, still the performance quality of the individuals often remains least changed (Thompson et al., 2019) due to habit formation or they may not recognise the difficulties they experience. They may also experience substantial troubles in functioning and well-being (Jefferies \& Ungar, 2020). Now habit formation thus impacts social interaction. If a habit of avoiding social interaction is practiced for a long time, then social anxiety or phobia can adverselyaffect the psychological development of individuals.

There can be numerouscauses behind social interaction anxiety. Among the many, earlylife events are crucial because childhood experiences pave the path of future developments. If a person's social interaction is impaired since childhood, then there is a high chance of developing social interaction anxiety in later life. Like in the present scenario of covid-19 pandemic, the children live in a world where direct social interactions are threatening to life. These children may suffer from social interaction anxiety in the future. A high level of social anxiety carries a higher prevalence of negative early life events (Binelli etal,, 2012)

There is high prevalence of social phobia among young adults, which has major negative consequences for the quality of life and necessitates early detection and treatment (Hajure \& Abdu, 2020), and thus, it can be controlled with appropriate education and intervention(Jefferies \& Ungar, 2020). And also, early detection and appropriate intervention (Mukherjee \& Hussain, 2020), along with psychotherapeutic treatments or psychological counseling and effective pharmacological treatment, can be effective in improving the quality of life for persons with anxiety disorders, and also there must be a thorough understanding of the impact of anxiety on quality of life amongindividuals (Mendlowicz \& Stein, 2000 ) so that they can be aware of the alarming signs of developing social interaction anxiety in specific or general situations which areharmful for theirlife.

But before getting affected by the social interaction anxiety and developing distorted meaning in life, there must be other interventions to control the prevalence of anxiety-inducing circumstances. Social approval and happiness can be ensured (Karasar \& Baytemir, 2018) where the scope of social interaction anxiety is less. That means controlling anxiety-inducing things will condition the individuals to react effectively with no negative feelings, and happiness of mind will also add positive meaning in life.

During the covid-19 pandemicperiod creating a positive environmentinside and outside the home is humaneresponsibility. Any illness and death attach negative emotions. So to keep the mind away from its direct and indirect effects, sustainable positive surroundings are what the world needs now. Happiness is the only thing that every individual wants. Even in hard times, people try to find a ray of hope. That must be the way of living. A positive view of life is needed to fight the psychosocial effects of a pandemic. A positive and healthy mind does not indulge negative psychological issues like anxiety in taking over the happinessand meaning oflife.

\section{CONCLUSION}

The findingsrevealed that gender playsan important role in determining meaning in life and social interaction anxiety among young adults. It clears the fact that individual differences are vital in human beings' lives that develop gradually with social interaction. The meaning of life primarily attachespositive 
Khazanah Sosial, Vol. 3 No. 3 : 130-137

Meaning in Life During Covid-19 Pandemic and Social Interaction Anxiety :The Relevant Facets Mayurakshee Gangopadhyay

feelings towards life and how effectively it grows within an individual. During the phase of the covid-19 pandemic, the meaning in life can be attributed differently to different individuals. But there is a common pattern in the growing social interaction anxiety due to the spread of the virus through human interaction. This gradually is impairaing the quality of life and happiness attached to it,leading to severe psychosocial problems. Through the practice of positive thinking, meaningful and healthy ways of living, the negative psychological effects of the pandemic can be controlled. Psychological counseling can help to protect the human mind and minimize the negativities attached to the covid-19 pandemic.

\section{REFERENCES}

Baber, H. (2021). Social interaction and effectiveness of the online learning-A moderating role of maintaining social distance during the pandemic COVID-19. Asian Education and Development Studies.

Banerjee, D., \& Rai, M. (2020). Social isolation in Covid-19: The impact of loneliness. International Journal of Social Psychiatry, 66 (6), 525-527.

Banerjee, D., Vaishnav, M., Rao, T. S. S., Raju, M., Dalal, P. K., Javed, A., Saha, G., Mishra, K. K., Kumar, V., \& Jagiwala, M. P. (2020). Impact of the COVID-19 pandemic on psychosocial health and well-being in South-Asian (World Psychiatric Association zone 16) countries: A systematic and advocacy review from the Indian Psychiatric Society. Indian Journal of Psychiatry, 62(Suppl 3), S343.

Binelli, C., Ortiz, A., Muñiz, A., Gelabert, E., Ferraz, L., S Filho, A., Crippa, J. A. S., Nardi, A. E., Subirà, S., \& Martín-Santos, R. (2012). Social anxiety and negative early life events in university students. Brazilian Journal of Psychiatry, 34, 69-74.

Carreno, D. F., Eisenbeck, N., Pérez-Escobar, J. A., \& García-Montes, J. M. (2021). Inner harmony as an essential facet of well-being: a multinational study during the COVID-19 pandemic. Frontiers in Psychology, 12, 911.

Chou, W.-P., Wang, P.-W., Chen, S.-L., Chang, Y.-P., Wu, C.-F., Lu, W.-H., \& Yen, C.-F. (2020). Voluntary reduction of social interaction during the COVID-19 pandemic in Taiwan: related factors and association with perceived social support. International Journal of Environmental Research and Public Health, 17(21), 8039.

Gangopadhyay, M. (2021). Values and Psychological Wellbeing of Youth: A Sustainable Interconnection. Khazanah Pendidikan Islam, 3(1), 30-40.

Hajure, M., \& Abdu, Z. (2020). Social Phobia and Its Impact on Quality of Life Among Regular Undergraduate Students of Mettu University, Mettu, Ethiopia. Adolescent Health, Medicine and Therapeutics, 11, 79.

Hemanth, L. K. (2020). Changing trends of social interaction during the pandemic and its effects on mental health-A student's perspective. Asian Journal of Education and Social Studies, 7-14.

Jefferies, P., \& Ungar, M. (2020). Social anxiety in young people: A prevalence study in seven countries. PLoS One, 15(9), e0239133.

Karasar, B., \& Baytemir, K. (2018). Need for Social Approval and Happiness in College Students: The Mediation Role of Social Anxiety. Universal Journal of Educational Research, 6(5), 919-927.

Kharshiing, K. D., Kashyap, D., Gupta, K., Khursheed, M., Shahnawaz, M. G., Khan, N. H., Uniyal, R., \& Rehman, U. (2021). Quality of life in the COVID-19 pandemic in India: Exploring the role of individual and group variables. Community Mental Health Journal, 57(1), 70-78.

King, P. E., Carr, D., \& Boitor, C. (2011). Religion, spirituality, positive youth development, and thriving. Advances in Child Development and Behavior, 41, 161-195.

Leray, E., Camara, A., Drapier, D., Riou, F., Bougeant, N., Pelissolo, A., Lloyd, K. R., Bellamy, V., Roelandt, J. L., \& Millet, B. (2011). Prevalence, characteristics and comorbidities of anxiety 
disorders in France: results from the "Mental Health in General Population" survey (MHGP). European Psychiatry, 26(6), 339-345.

Mattick, R. P., \& Clarke, J. C. (1998). Development and validation of measures of social phobia scrutiny fear and social interaction anxiety. Behaviour Research and Therapy, 36(4), 455470.

Mendlowicz, M. V, \& Stein, M. B. (2000). Quality of life in individuals with anxiety disorders. American Journal of Psychiatry, 157(5), 669-682.

Mukherjee, K., \& Hussain, D. (2020). The role of peer victimization and emotion dysregulation in social anxiety and disordered eating comorbidity in young adults. Current Psychology, 115.

Steger, M. F. (2006). Development and validation of the Meaning in Life Questionnaire: A measure of eudaimonic well-being. Dissertation Abstracts International: Section B: The Sciences and Engineering, 66, 4257.

Sushma, B., Padmaja, G., \& Agarwal, S. (2016). Well-being, psychosocial problems and social interaction anxiety in children. International Journal of Indian Psychology, 3(4), 30-43.

Thompson, T., Van Zalk, N., Marshall, C., Sargeant, M., \& Stubbs, B. (2019). Social anxiety increases visible anxiety signs during social encounters but does not impair performance. $B M C$ Psychology, 7(1), 1-9.

Wong, P. T. P. (2013). Toward a dual-systems model of what makes life worth living. In P.T.P. Wong (Ed.), The human quest for meaning (pp. 49-68). Routledge.

Wong, P. T. P. (2014). Viktor Frankl's meaning-seeking model and positive psychology. In A. Batthyany \& P. Russo-Netzer (Ed.), Meaning in positive and existential psychology (pp. 149184). Springer.

Xu, Y., Schneier, F., Heimberg, R. G., Princisvalle, K., Liebowitz, M. R., Wang, S., \& Blanco, C. (2012). Gender differences in social anxiety disorder: Results from the national epidemiologic sample on alcohol and related conditions. Journal of Anxiety Disorders, 26(1), 12-19. 